\title{
Research on Tax Contribution of Tourism in Guangdong Province
}

\author{
Qiang Chen \\ College of Economics, Jinan University, Guangzhou, China \\ Email: chinachenqiang@126.com
}

How to cite this paper: Chen, Q. (2018) Research on Tax Contribution of Tourism in Guangdong Province. Modern Economy, 9, 980-987.

https://doi.org/10.4236/me.2018.95062

Received: April 7, 2018

Accepted: May 13, 2018

Published: May 16, 2018

Copyright $\odot 2018$ by author and Scientific Research Publishing Inc. This work is licensed under the Creative Commons Attribution International License (CC BY 4.0).

http://creativecommons.org/licenses/by/4.0/

\section{Abstract}

In recent years, tourism has become an important part of China's emerging services industry, and is regarded as the "sunrise industry" of the 21 st century. Relevant data from China National Tourism Administration show that the number of domestic tourists in China reached 5 billion times in 2017, and the total number of inbound and outbound tourists in China reached 270 million. The annual domestic tourism revenue reached 4.57 trillion Yuan and the international tourism revenue reached $\$ 123.4$ billion. According to the preliminary calculation of China National Tourism Administration, the comprehensive contribution of tourism to China's GDP in 2017 has reached 9.13 trillion Yuan, and tourism brings the employment population to 79.9 million. With the continuous development of society, the role of tourism in promoting national economic development will become increasingly prominent. Guangdong province is located at the southernmost point of mainland China, with a long history and rich natural and cultural tourism resources. 2018 is the 40th anniversary of China's reform and opening up. As the forefront of China's reform and opening up, Guangdong province is an important tourist reception center and tourism center in China, and the tourism industry has always been in the leading position in China. For years, Guangdong province ranked first among China's provincial economic rankings. The rapid development of tourism in Guangdong province plays an important role in the economic development of Guangdong province. This paper studies the tax contribution of tourism in Guangdong province by combining the relevant data of macro tax burden (tax rate). The study consists of three perspectives. First, Guangdong province is compared with Jiangsu, Shandong and Zhejiang provinces. Second, the comparison of eastern China. Third, Guangdong province is compared with the national average. Based on the research, this paper concludes that tourism tax contribution of Guangdong province is low. This paper studies the tax contribution of tourism in Guangdong province and puts forward some suggestions to improve the tax contribution of tourism in 
Guangdong province.

\section{Keywords}

Guangdong Province, The Tourism Industry, Tax, Contribution

\section{Introduction}

In recent years, tourism has become an important part of China's emerging services industry, and is regarded as the "sunrise industry" of the 21st century. Tourism can meet people's growing material and cultural needs. Through tourism, people can rest in physical and mental health and improve their health. People can broaden their horizons, increase their knowledge and promote social progress. The development of tourism on the basis of the whole national economic development level and subject to the constraints, at the same time, directly or indirectly promote the development of the relevant departments of the national economy, and promote these departments continue to improve and perfect facilities, increase the service project, improve the quality of service. With the continuous development of society, the role of tourism in promoting national economic development will become increasingly prominent.

Relevant data from China National Tourism Administration show that the number of domestic tourists in China reached 5 billion times in 2017, an increase of $12.8 \%$ over the same period last year; In 2017, the total number of inbound and outbound tourists in China reached 270 million, up 3.7\% from the same period last year; Annual domestic tourism revenue reached 4.57 trillion Yuan, up $15.9 \%$ from the same period last year; International tourism revenue reached $\$ 123.4$ billion, up $2.9 \%$ compared with the same period last year. According to preliminary calculation of China National Tourism Administration, the comprehensive contribution of tourism to China's GDP has reached 9.13 trillion Yuan in 2017, accounting for $11.04 \%$ of GDP; The number of direct employment in tourism is 28.25 million, and the total number of direct employment and indirect employment is 79.9 million, accounting for 10.28 percent of China's total employment.

Guangdong province is located at the southernmost point of mainland China and has a long history and rich natural and cultural tourism resources. Information of Tourism Administration of Guangdong province shows that as of September 8, 2017, there are 12 national AAAAA tourist attractions in Guangdong province. Data from Statistics Bureau of Guangdong province show that from 2005 to 2016, the total tourism revenue of Guangdong province rose from 188.26 billion Yuan to 1043.381 billion Yuan; Among them, domestic tourism revenue rose from 135.354 billion Yuan to 920.029 billion Yuan, and the foreign exchange income rose from 52.906 billion Yuan to 123.352 billion Yuan; Guangdong's total tourism revenue has increased from $8.35 \%$ to $13.12 \%$ of Guangdong's GDP. But Guangdong province tourism industry is facing such a prob- 
lem: absolute tourism revenue contribution is very big, but from the perspective of tax contribution analysis, Guangdong tourism tax contribution on a national scale in a low level. Based on the research, this paper concludes that tourism tax contribution of Guangdong province is low. This paper studies the tax contribution of tourism in Guangdong province and puts forward some suggestions to improve the tax contribution of tourism in Guangdong province. This paper has some limitations, because of the lack of relevant data, so this paper mainly studies the tax contribution for four consecutive years. This paper studies the tax contribution of tourism enterprises by calculating the tax burden of tourism enterprises.

\section{Literature Review}

\subsection{Tourism Tax}

According to the investigation and research on the tax situation of tourism industry, Shang di [1] et al. pointed out that although the tourism industry is developing continuously, the tax authorities have received more and more complaints about the tourism tax. Li xiaore [2] et al. analyzed the basic principles of tourism tax reform and put forward some countermeasures. Wang jialiu [3] analyzed the problems in the tourism tax collection and management. Jiang ping [4] et al. has analyzed the tax policies and management deficiencies of the tourism industry. Qiu yulian [5] et al. analyzed the problems in China's tourism tax policy and put forward some policy suggestions.

\subsection{Tax Contributions}

Wang qiao [6] et al. used relevant tax contribution indicators (including tax growth rate, macro tax burden, marginal tax burden, etc.) to make an empirical analysis of the tax contribution of China's circulation industry. Xi weiqun [7] used multiple indicators (macro tax burden, tax flexibility and tax coordination coefficient) to calculate the tax contribution of China's first industry, secondary industry and tertiary industry. Bai jingming [8] et al. studied the tax contribution of China's manufacturing industry and analyzed the tax structure, industry structure, regional structure and internal and foreign enterprise structure of manufacturing tax contribution. Wang yunli [9] studied the contribution of China's logistics industry to tax revenue.

Through the analysis of the above literatures, it can be seen that there is relatively little research on the combination of tourism and tax contribution. For the study of tourism, scholars prefer to analyze the influence of tax policy on tourism in theory and raise questions and suggestions. For the study of tax contribution, more focus on logistics, manufacturing and so on. Based on the actual data of Guangdong province, this paper will analyze the tax contribution of tourism in Guangdong province.

\section{Tourism Tax Contribution of Guangdong Province}

In this chapter, tourism enterprises are used as carriers to study the tax contri- 
bution of tourism in Guangdong province as a measure of tax burden (macro tax). The tourism enterprises in this article include travel agencies, star hotels and tourist attractions. The tax rate (macro tax) in the study is the ratio of "operating tax and additional" to "operating income". The data is from the yearbook of China tourism statistics. The unit of these two indicators in the study is ten thousand yuan. This chapter studies three perspectives, one is the comparison between Guangdong province and Jiangsu province, Shandong province and Zhejiang province, the second is the comparison of eastern regions, and the third is the comparison between Guangdong province and the national average level. Step by step, it clearly shows the current tax contribution status of tourism in Guangdong province.

\subsection{Comparison between Guangdong Province and Jiangsu Province, Shandong Province and Zhejiang Province}

For many years, Guangdong, Jiangsu, Shandong and Zhejiang provinces have occupied the top four in the economic ranking of China's provinces, so the tax rate (macro tax) of tourism enterprises in these four provinces is compared.

Table 1 shows the operating income of tourism enterprises in 4 provinces (Jiangsu, Zhejiang, Shandong and Guangdong). Table 2 shows the business taxes and additional taxes of tourism enterprises in 4 provinces (Jiangsu, Zhejiang, Shandong, Guangdong). Table 3 shows the tax rate of tourism enterprises in 4 provinces (Jiangsu, Zhejiang, Shandong, Guangdong).It can be seen from the table that the tax rate of tourism enterprises in Guangdong province is smaller than that of other three regions from 2012 to 2015.

\subsection{A Comparison of Eastern China}

The eastern part of this study includes Beijing, Tianjin, Hebei, Liaoning, Shanghai,

Table 1. Operating income of four provincial tourism enterprises.

\begin{tabular}{ccccc}
\hline Region & 2012 & 2013 & 2014 & 2015 \\
\hline Jiangsu & 4548909.1 & 4512251 & 4621195.66 & 5444485.25 \\
Zhejiang & 4957832.12 & 4824548.32 & 5204185.25 & 5052214.23 \\
Shandong & 3422359.42 & 3196824.46 & 2984284.72 & 3336879.25 \\
Guangdong & 7881553.41 & 8377383.22 & 9059146.51 & 8867276.5 \\
\hline
\end{tabular}

Note: The data is from the yearbook of China tourism statistics (supplement).

Table 2. Business taxes and additions to four provincial tourism enterprises.

\begin{tabular}{ccccc}
\hline Region & 2012 & 2013 & 2014 & 2015 \\
\hline Jiangsu & 124395.49 & 119394.83 & 112371.31 & 117933 \\
Zhejiang & 141362.53 & 143177.19 & 143424.72 & 137947.62 \\
Shandong & 106530.12 & 101756.61 & 90590.74 & 85761.4 \\
Guangdong & 206384.4 & 197020.05 & 173341.51 & 176473.07
\end{tabular}

Note: The data is from the yearbook of China tourism statistics (supplement). 
Table 3. Tax rate for four provincial tourism enterprises.

\begin{tabular}{ccccc}
\hline Region & 2012 & 2013 & 2014 & 2015 \\
\hline Jiangsu & $2.73 \%$ & $2.65 \%$ & $2.43 \%$ & $2.17 \%$ \\
Zhejiang & $2.85 \%$ & $2.97 \%$ & $2.76 \%$ & $2.73 \%$ \\
Shandong & $3.11 \%$ & $3.18 \%$ & $3.04 \%$ & $2.57 \%$ \\
Guangdong & $2.62 \%$ & $2.35 \%$ & $1.91 \%$ & $1.99 \%$ \\
\hline
\end{tabular}

Jiangsu, Zhejiang, Fujian, Shandong, Guangdong and Hainan. According to the operating income, business tax and additional of tourism enterprises in the eastern provinces (municipalities directly under the central government) from 2012 to 2015 , the tax rate of the corresponding tourism enterprises can be obtained.

Table 4 shows the operating income of tourism enterprises in 11 provinces. Table 5 shows the business tax and the addition of tourism enterprises in 11 provinces. Table 6 shows the tax rate of tourism enterprises in 11 provinces. Using SPSS software to cluster analysis of 11 provinces in eastern China, the eastern part of China was divided into 3 categories. There are three provinces (Beijing, Shanghai, Guangdong) belong to the category 1, there are seven provinces (Tianjin, Hebei, Liaoning, Jiangsu, Zhejiang, Shandong, Hainan) belong to the second class, one provincial (Fujian) belong to the class 3 . The first class represents four years of tourism enterprises tax burden rate is low, the second class represents four years of tourism enterprises tax burden rate is at medium level, the third class represents four years of tourism enterprises tax burden rate is on the high side. Guangdong province is in the first category, namely Guangdong province four years of tourism enterprise tax burden rate is low.

\subsection{Comparison between Guangdong and the National Average}

Table 7 shows the tax rate of national tourism enterprises. Table 8 shows the tax rate of Guangdong tourism enterprises. Through the table, we can see that the tax rate of tourism enterprises in Guangdong province is lower than the national average. In 2012, the tax rate of the national tourism enterprises was $2.95 \%$, and the tax rate of tourism enterprises in Guangdong province was 2.62\%. In 2013, the tax rate of national tourism enterprises was $2.57 \%$, and the tax rate of tourism enterprises in Guangdong province was $2.35 \%$. In 2014, the tax rate of national tourism enterprises was $2.40 \%$, and the tax rate of tourism enterprises in Guangdong province was $1.91 \%$. In 2015, the tax rate of national tourism enterprises was $2.55 \%$, and the tax rate of tourism enterprises in Guangdong province was $1.99 \%$.

\section{Conclusions}

In front, we analyzed the tax rate of Guangdong tourism enterprises through three perspectives. First, Guangdong province is compared with Jiangsu, Shandong and Zhejiang provinces. Second, we divide eastern China into three categories. Third, Guangdong province is compared with the national average. 
Table 4. Operating income of 11 provincial tourism enterprises.

\begin{tabular}{ccccc}
\hline Region & 2012 & 2013 & 2014 & 2015 \\
\hline Beijing & 8482295.05 & 8959963.6 & 10349254.09 & 9983593.35 \\
Tianjin & 647704.61 & 706717.94 & 896868.33 & 725496.86 \\
Hebei & 1164258.37 & 1291570.56 & 1082493.91 & 999955.31 \\
Liaoning & 1454258.14 & 1660783.06 & 1537457.46 & 1870530.77 \\
Shanghai & 6745482.54 & 7606434.94 & 8208654.52 & 9363006.76 \\
Jiangsu & 4548909.1 & 4512251 & 4621195.66 & 5444485.25 \\
Zhejiang & 4957832.12 & 4824548.32 & 5204185.25 & 5052214.23 \\
Fujian & 2360328.17 & 2647804.14 & 2770516.5 & 3144584.05 \\
Shandong & 3422359.42 & 3196824.46 & 2984284.72 & 3336879.25 \\
Guangdong & 7881553.41 & 8377383.22 & 9059146.51 & 8867276.5 \\
Hainan & 1006270.63 & 1049806.58 & 1155006.05 & 1096129.79 \\
\hline
\end{tabular}

Note: The data is from the yearbook of China tourism statistics (supplement).

Table 5. Business taxes and additions to 11 provincial tourism enterprises.

\begin{tabular}{ccccc}
\hline Region & 2012 & 2013 & 2014 & 2015 \\
\hline Beijing & 191249.65 & 180883.67 & 180573.37 & 185962.61 \\
Tianjin & 21211.22 & 21380.34 & 19701.28 & 18097.13 \\
Hebei & 47943.99 & 49039.09 & 37059.02 & 38056.98 \\
Liaoning & 43649.04 & 43634.8 & 37854.76 & 38749.26 \\
Shanghai & 118852.54 & 117541.87 & 152010.67 & 139643.75 \\
Jiangsu & 124395.49 & 119394.83 & 112371.31 & 117933 \\
Zhejiang & 141362.53 & 143177.19 & 143424.72 & 137947.62 \\
Fujian & 65653.36 & 70770.45 & 71787.09 & 169638.05 \\
Shandong & 106530.12 & 101756.61 & 90590.74 & 85761.4 \\
Guangdong & 206384.4 & 197020.05 & 173341.51 & 176473.07 \\
Hainan & 31133.89 & 33034.22 & 32511.81 & 36027.67 \\
\hline
\end{tabular}

Note: The data is from the yearbook of China tourism statistics (supplement).

The tax burden of Guangdong tourism enterprises directly reflects the tax contribution of Guangdong tourism industry. We can conclude that Guangdong's tourism tax contribution has been low. The relevant departments should improve the tax contribution of tourism in Guangdong province through improvement in many aspects. For example, relevant departments can improve the economic environment, improve the tax system and strengthen tax collection and administration. This paper mainly makes suggestions from 3 aspects.

1) The economic environment

Guangdong province should strengthen tourism promotion. Tourism promotion can promote the rapid growth of tourism revenue. Now WeChat and Weibo are very popular, and Guangdong province should actively cooperate with WeChat and Weibo to launch tourism advertisements on WeChat and Weibo. 
Table 6. Tax rate for 11 provincial tourism enterprises.

\begin{tabular}{ccccc}
\hline Region & 2012 & 2013 & 2014 & 2015 \\
\hline Beijing & $2.25 \%$ & $2.02 \%$ & $1.74 \%$ & $1.86 \%$ \\
Tianjin & $3.27 \%$ & $3.03 \%$ & $2.20 \%$ & $2.49 \%$ \\
Hebei & $4.12 \%$ & $3.80 \%$ & $3.42 \%$ & $3.81 \%$ \\
Liaoning & $3.00 \%$ & $2.63 \%$ & $2.46 \%$ & $2.07 \%$ \\
Shanghai & $1.76 \%$ & $1.55 \%$ & $1.85 \%$ & $1.49 \%$ \\
Jiangsu & $2.73 \%$ & $2.65 \%$ & $2.43 \%$ & $2.17 \%$ \\
Zhejiang & $2.85 \%$ & $2.97 \%$ & $2.76 \%$ & $2.73 \%$ \\
Fujian & $2.78 \%$ & $2.67 \%$ & $2.59 \%$ & $5.39 \%$ \\
Shandong & $3.11 \%$ & $3.18 \%$ & $3.04 \%$ & $2.57 \%$ \\
Guangdong & $2.62 \%$ & $2.35 \%$ & $1.91 \%$ & $1.99 \%$ \\
Hainan & $3.09 \%$ & $3.15 \%$ & $2.81 \%$ & $3.29 \%$ \\
\hline
\end{tabular}

Table 7. National tourism enterprise tax rate.

\begin{tabular}{cccc}
\hline Year & Operating income & Business tax and additional & Tax rate \\
\hline 2012 & 62541346.79 & 1845297.36 & $2.95 \%$ \\
2013 & 64185675.98 & 1651223.72 & $2.57 \%$ \\
2014 & 67320754.37 & 1615537.48 & $2.40 \%$ \\
2015 & 68983295.81 & 1757629.03 & $2.55 \%$ \\
\hline
\end{tabular}

Note: The data is from the yearbook of China tourism statistics (supplement).

Table 8. Guangdong provincial tourism enterprise tax rate.

\begin{tabular}{cccc}
\hline Year & Operating income & Business tax and additional & Tax rate \\
\hline 2012 & 7881553.41 & 206384.4 & $2.62 \%$ \\
2013 & 8377383.22 & 197020.05 & $2.35 \%$ \\
2014 & 9059146.51 & 173341.51 & $1.91 \%$ \\
2015 & 8867276.5 & 176473.07 & $1.99 \%$
\end{tabular}

Note: The data is from the yearbook of China tourism statistics (supplement).

Guangdong province should launch travel advertisements at China's high-speed railway station. Guangdong province should vigorously develop the Guangdong free trade area and attract tourists to shopping in the Guangdong free trade zone. The tax effect of tourism shopping is obvious. Guangdong province should strengthen the training of tourism staff, enhance their service awareness and improve their skills. Guangdong province should improve traffic conditions and accommodation conditions to improve tourist satisfaction. Guangdong province should take necessary measures to promote balanced development of tourism, so that the developed cities can help the less developed cities.

2) The tax system 
Some unreasonable fees should be abolished. It is suggested to levy a consumption tax on outbound tourism. Some western countries have imposed a consumption tax on outbound tourism, and China should also impose a consumption tax on outbound tourism, given the current situation in China. Tourism contracts between travel agencies and tourists should also be included in the stamp duty collection. Guangdong province should formulate appropriate tax incentives to promote the development of tourism enterprises. The better development of tourism enterprises will also promote the faster growth of tourism tax in Guangdong province.

3) Tax collection and administration

Guangdong province should strengthen the publicity of tax laws and promote the observance of laws by tourism enterprises. For illegal enterprises, increase punishment and increase the cost of crime. Enterprise financial system management should be strengthened. Regulation of individual income tax in tourism should be strengthened. Promote the deep integration of tax collection, management and Internet.

\section{References}

[1] Shang, D., Yao, F. and Su, J. (2008) Investigation of the Tourism Tax Situation. China Taxation, 2, 52-54.

[2] Li, X.R. and Xia, J.C. (2009) The Basic Principle and Countermeasure Idea of Tax Reform of Tourism Industry. International Taxation in China, 5, 22-25.

[3] Wang, J.L. (2010) Thinking on Tax Collection and Management of Tourism Industry. Market Weekly, 11, 110-111.

[4] Jiang, P., Zhang, H.B. and Jiang, B.Z. (2011) Tourism Tax Policy and Management Analysis. Taxation Research, 10, 80-82.

[5] Qiu, Y.L. and Zhou, S. (2011) Problems and Countermeasures of China's Tourism Tax Policy. Commercial Accounting, 14, 66-67.

[6] Wang, Q., Xi, W.Q., Wang, Z.W. and Zhang, Z.F. (2011) Empirical Analysis of Tax Contribution of China's Circulation Industry. Economic Review, 1, 105-115.

[7] Xi, W.Q. (2015) Tax Contribution and Policy Adjustment of Three Kinds of Industries in China. Contemporary Finance and Economics, 9, 35-44.

[8] Bai, J.M. and He, P. (2017) Research on Tax Contribution of Chinese Manufacturing Industry. Price Theory and Practice, 3, 19-23.

[9] Wang, Y.L. (2017) A Brief Analysis of the Contribution of Logistics Industry to China's Tax Revenue. Economic and Trade, 9, 236. 